This PDF is a selection from an out-of-print volume from the National Bureau of Economic Research

Volume Title: The Volume of Consumer Instalment Credit, 1929-1938

Volume Author/Editor: Duncan McC. Holthausen, Malcolm L. Merriam and Rolf Nugent

Volume Publisher: NBER

Volume ISBN: 0-87014-123-6

Volume URL: http://www.nber.org/books/holt40-1

Publication Date: September 1940

Chapter Title: The Volume of Consumer Instalment Credit, 1929-38

Chapter Author: Duncan McC. Holthausen, Malcolm L. Merriam, Rolf Nugent

Chapter URL: http://www.nber.org/chapters/c5385

Chapter pages in book: (p. 1 - 12) 


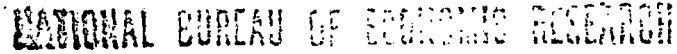 \\ National Bureau of Economic Research
}

A TON-PROFIT MEMtBERSHIP CORPORATION FOR IMPARTIAL STUDIES IN ECONOMIC AND SOCIAL SCIENCE

\begin{tabular}{lll}
\hline Bulletin 79 & I 819 BROADWAY, NEW YORK & September 1,1940 \\
\hline \hline
\end{tabular}

Copyright, 1940, National Burean of Economic Research, Inc.

\section{The Volume of Consumer Instalment Credit, 1929-1938}

\author{
DUNCAN MCC. HOLTHAUSEN \\ Research Associate, Financial Research Staff, National Bureau of Economic Research \\ in collaboration with \\ MALCOLM L. MERRIAM \\ Chief, Credit Analysis Unit, Marketing Research Division, Bureau of Foreign \\ and Domestic Commerce, United States Department of Commerce \\ and \\ ROLF NUGENT \\ Director, Department of Consumer Credit Studies, Russell Sage Foundation
}

One of the most notable developments in our national economy during the past few decades has been the growth of credit extended to consumers on instalment termis. In recent years there bas been an increasing recognition of the fact that this type of credit is exerting a profound and widespread influence on national purchasing babits, on methods of distribution and finance, and on the whole financial structure of the country.

While the importance of consumer instalment credit is undisputed, discussion of its exact infuence bas been bampered by the scarcity of adequate statistical data about it. True, the Russell Sage Foundation recently published a comprebensive series of figures for the outstanding amount of consumer credit as a whole, broken down by types of credit agency; but the nature of its material prevented segregation of instalment credit, which is undoubtedly the most significant part of the whole. Previous estimates of this particular type of credit bave been based on data either fragmentary or incomplete in coverage.

Tbis bulletin presents the first consistent series of annual and monthly estimates of the volume of consumer instalment credit, co:ering the period from 1929 to 1938 inclusive. The data were prepared as a collaborative undertaking of the National Bureaul of Economic Research, the Russell Sage Foundation and the Bureau of Foreign and Domestic Commerce of the United States Department of Conmerce. For several years prior to the present collaborative effort, each of these agencies was independently studying some phase of consumer credit, and interpreting its growth and change. The final development of the estimates pre- sented in this bulletin constitutes an outstanding illustration of the fruitfulness of cooperative research.

In preparing the estimates it was necessary to draw upon many sources, and to request special information from a number of private agencies actively engaged in consumer instalment financing. These requests were received with uniform cordiality, and we take pleasure in acknowledging the generous contributions of material. Methods of estimate were submitted to a number of specialists in the field and their criticisnis and suggestions are likewise acknowledged with appreciation.

Because of gaps in the basic working materials, methods for estimating were modified according to availability of data. Consequently, we can attribute only approximate accuracy to these figures. Future revisions to increase the precision and value of the series will be made, bowever, as materials become more abundant and working methods more exact.

In view of the continuing need of business and public agencies for such data, the United States Department of Conmerce bas agreed to bring these series up to date and to maintain them on a current basis in the. future. The collection of data and preparation of estimates, which bas already begun, is centralized in the Credit Analysis Unit of the Division of Marketing Research, Bureau of Foreign and Domestic Conmerce.

JAMES W. YOUNG, Director

Bureau of Foreign and Domestic Conmerce

U.S. Department of Conmerce

RALPH A. YOUNG, Director

Financial Researcb Program

National Bureau of Economic Research 
THE TERM consumer instalment credit, as employed in this study, means credit extended to consumers which requires them to repay principal and interest in prescheduled amounts at regular intervals. Consumer instalment credit as thus defined is extended by two types of institutions-retail establishments selling goods, and cash-lending agencies, which advance funds. Accordingly, the estimates presented in this monograph were derived from two bodies of data-retail instalment sales and cash instalment loans. The retail establishments here included fall into six classifications: dealers in new and used passenger automobiles, department stores, furniture stores, household appliance stores, jewelry stores, and a miscellaneous group of "all other stores." Institutions offering cash instalment loans include five groups -personal loan departments of commercial banks, credit unions, industrial banking companies, personal finance companies, and unregulated lenders. To supplement the estimates for these five types of cash-lending agencies, a sixth series was developed covering loans insured by the Federal Housing Administration under Title I of the National Housing Act. This series includes all notes of $\$ 2,000$ or less which may be considered consumer credit.

Four phases of instalment credit are covered by our study - the volume of credit granted, the volume of repayments, the amount of outstanding receivables, and the net credit change. The first two are self-explanatory. Outstandings represent the difference between credit granted and repayments; i.e., the amount of consumer instalment debt in existence at a specified point of time; average outstandings represent the mean amount of such debt in existence over a specified interval of time. Net credit change is the change in outstandings during a specified time interval.

Except where otherwise noted, all series extend from 1929. through 1938, both annually and monthly, and cover four items-credit granted, repayments, outstandings, and net credit change.

The types of retail establishments for which estimates of instalment credit were developed are classified in general according to the 1935 Census of Business. ${ }^{1}$ The automobile dealer group constitutes the one important exception; the estimates for this group were worked out from numbers of cars sold, as reported to the Automobile Manufacturers Association. The instalment transactions of establishments which are not treated in the present survey are primarily grants of producer credit as distinguished from consumer credit.

Estimates for the five types of institutions in the cash loan group are based upon compilations of the Russell

1 See Census of Business: 1935, Retail Distribution, vol. I, pp. $4-03$ through $4-08$.
Sage Foundation, ${ }^{2}$ whose classifications have been followed with regard to both definition and coverage. The estimates for loans insured under Title I of the National Housing Act are derived from data contained in annual reports of the Federal Housing Administration.

The reader is cautioned to bear in mind the following characteristics and limitations of the estimates prepared in this study:

I. All outstandings estimates listed by type of retail establishment represent the amount of consumer debt originating in retail instalment sales regardless of whether the retailer himself carries the instalment paper as an account receivable item or has sold part or all of the instalment paper to outside agencies (i.e., sales finance companies, commercial banks, industrial banking companies, and all other purchasers of consumer instalment notes from retailers).

2. Prepayments of instalment accounts, renewals of notes, delinquencies and repossessions are not accounted for in the repayments and outstandings estimates for the automobile dealer series.

3. Estimates of credit granted for all types of cashlending institutions include renewals of old loan balances; the repayments series include accounting collections on loans renewed. Thus the amount of credit granted (or loans made) by cash-lending agencies cannot be considered to refer exclusively to new cash advanced, and the volume of repayments to such agencies cannot be considered to refer only to repayments on new loans.

4. Repayments include charge-offs on bad loans in all series except that for automobile dealers.

5. Interest charges are not included in the personal finance company series, since this type of agency makes its charge each month on the unpaid balance and does not include the charge as a part of the amount of the loan or as a part of the loan balance outstanding. Roughly three-fourths of all credit unions use a similar lending technique and, to that extent, the credit union series exclude interest charges.

6. The series on loans insured by the Federal Housing Administration contain a small amount of duplication with other series in the study.

A monograph under the same title as this Bulletin, to be published shortly, will present complete tables covering all the series herein described. Appendix D of this monograph describes in detail the methods of estimate employed for the several instalment credit series, and indicates the limitations to which they are subject.

2 See Russell Sage Foundation, Consumer Credit and Economic Stability, by Rolf Nugent (1939), Ch. XIII. 


\section{Estimates of Retail Instalment Credit}

According to our estimates, the dollar amount of consumer debt arising from retail instalment transactions reached an all-tinie peak in 1937 . In that year average outstandings totaled $\$ 2,641,300,000$, the volume of credit granted was $\$ 3,666,800,000$, and repayments came to $\$ 3,392,400,000$.

During the ten-year period covered by our estimates, the low point for credit granted was 1932, when it stood at $\$ 1,363,500,000$. Its 1933 rolume was $\$ 1,584$,100,000, 16 percent above 19:2. Because debts incurred just prior to and during 193: were paid off at an unusually slow rate, average outstandings did not reach their low point $\left(\$_{1,052,500,000)}\right)$ until a year later than credit granted. The peak years for these two items were widely separated; credit granted was highest in 1929, when it amounted to $\$ 4,29 \varsigma_{4} 00$, 000, but average outstandings did not reach their high point until 1937. This divergence between the peak of outstandings and that of credit granted reflects increasingly liberal credit terms during the ten-year period, particularly the tendency to increase the length of contracts, since any increase in contract length tends to prolong the time during which a given amount of credit remains outstanding.

Retail credit granted, repayments, and average outstandings fluctuated widely in amount and showed similar percentage changes from their peak to trough and trough to peak years. Between 1929 and i 932 credit granted decreased 68 percent; between 1932 and 1937 it increased 169 percent. Repayments and average outstandings declined 64 percent and 57 percent respectively between 1929 and 1933 , and rose 136 percent and 15 I percent respectively between 1933 and 1937.

Despite the striking increase in credit granted from 1932 to 1937 , its volume in 1937 was approximately 15 percent below the 1929 peak. Repayments during 1937 . were 9 percent lower than in 1929, whereas average outstandings were 7 percent above i929.

The three items, however, showed somewhat different cyclical patterns. The rolume of credit granted declined rapidly from the 1929 figure; in 1930 it fell off 22 percent. Repayments and average outstandings declined only slightly, the former dropping 2 percent and the latter 6 percent. In 1933 , credit granted rose 16 percent over 1932, but repayments to liquidate instalment debt declined 28 percent, and average outstandings declined 18 percent. In 1938 there was a sharp decline in the rolume of credit granted, but only a moderate decrease in repayments and in average outstandings.

Month-end retail instalment indebtedness over the ten-year period was highest at the end of September
1937 and lowest at the end of March 1933. Before 1933, retail instalment debt had been highest at the close of October 19:9. It seems reasonable to suggest, therefore, that the cycles in retail instalment debt move closely with the general swings of business.

There were marked fluctuations in outstanding debt from peak to low months of business activity. For example, from October 1929 to March 1933 there was a decrease of 67 percent in the end-of-month outstandings, followed by an increase of 220 percent from March 1933 to September 1937, to a point 6 percent above the previous peak at the close of October 1929. A decrease of 24 percent occurred between September 1937 and December 1938. Chart I presents month-end outstandings for the five principal retail series, combined and singly. ${ }^{3}$

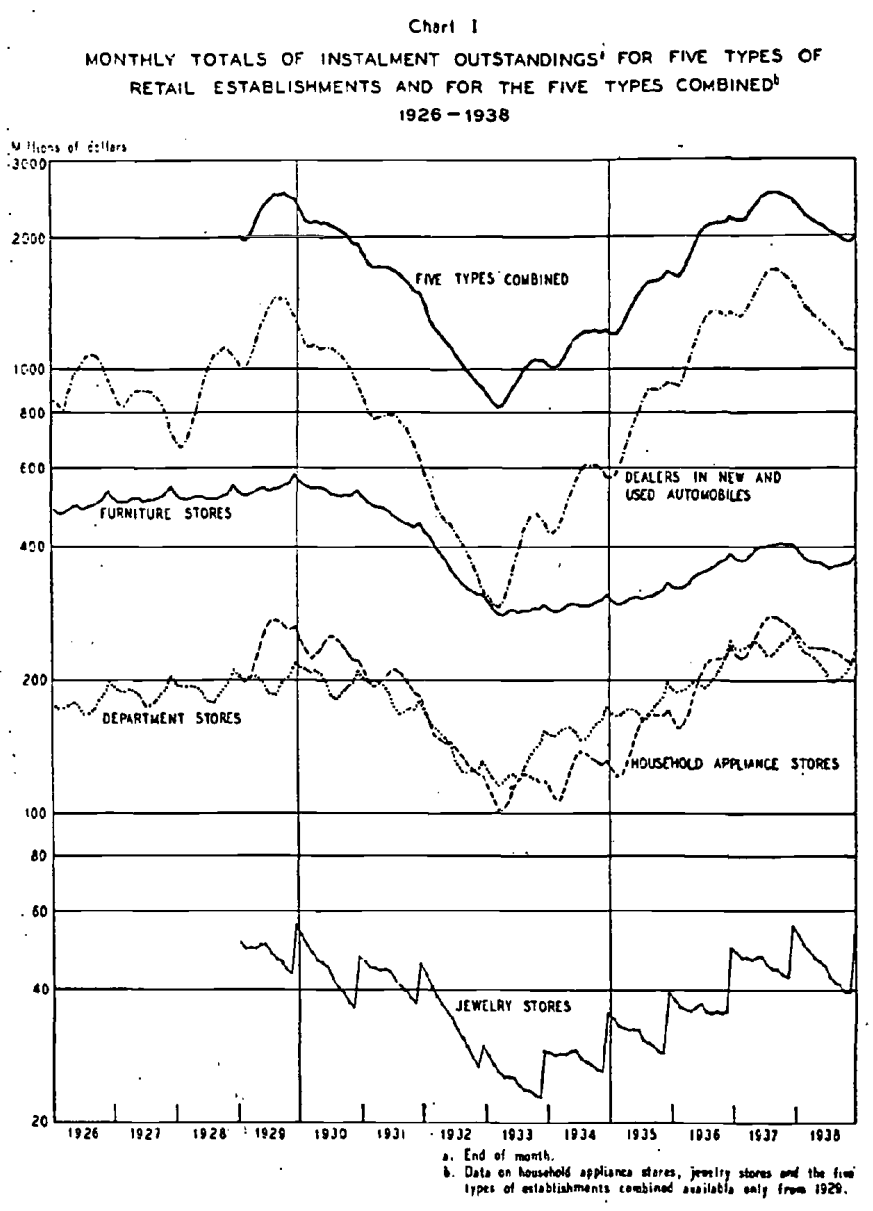

There are two key reasons for these wide cyclical swings in retail instalment credit. First and most important, thel consumer instalment market tends to center about high-priced durable goods, which consumers are not likely to purchase in periods of depression when 3 "All other stores" omitted. 
they are unsure of their future income, but which ther do acquire in periods of recovery when their economic outlook seems brighter. Second, credit grantors do not wish to make deferred payment sales or loans to individuals whose incomes do not meet the qualifications for an acceptable deferred payment risk. Naturally, therefore, in periods of economic decline many individuals to whom instalment credit facilities had hitherto been arailable night find themselves automatically disqualified from the use of such credit as a result of reduced incomes or unemployment.

Of the five types of retail establishments shown in Chart I, month-end outstandings arising from instalment sales of automobiles declined most sharply in the period of business recession 1929-33, falling off 80 percent from August 1929 to March 1933 . Instalment debt occasioned by department store sales showed the least violent drop, yet fell $4^{8}$ percent from December 1929 to March 1933. Decreases for the other three types of retail establishments ranged between these extremes. Increases from these 1933 low points to the 1937 high points show similar tendencies among the various outlets. Automobile instalment debt rose 475 percent, reaching a point 16 percent above its preceding peak in August 1929; while department store debt increased one-fourth as much ( 123 percent), reaching a point 17 percent above its preceding peak, in December 1929. Instalment debt incurred through household appliance stores and jewelry stores rose 175 percent and 143 percent respectively from the low points of 1933 to the high points of 1937 ; compared to 1929 levels household appliance store debt was 2 percent higher and jewelry store debt was about the same. Retail sales of furniture revived slowly, and debt from this source rose only 44 percent between 1933 and 1937, the 1937 figure being about one-third lower than the 1929 level.

Throughout the period studied, automobile purchases were the most important single source of retail instalment credit. In 1929 they were 55.4 percent of all such credit, and in 1937 they were 58.4 percent. In 1932, however, automobile instalment credit granted was only 42.3 percent of the total, and in $193^{8}$ it was 50.9 percent, while the percentages for department stores and for "all other stores" increased in those years. The percentage of total credit extended by department stores averaged 12 percent during this period; by furniture stores, 15 percent; by household appliance stores, about to percent; by "all other stores," about to percent; and by jewelry stores, between 2 and 3 percent.

The duration of instalment indebtedness, which represents the average length of time consumed in paying out debts, varied from 12 to 26 months over the tenyear period covered by our estimates. ${ }^{4}$ On the average, This duration of indebtedness is not the same as contract length, i.e., the specified number of months of an original sales contract. it was longest for the furniture, store group, where the payment period ranged from 18 to 26 months, and shortest for the department store group, where it was about 12 months." Chart II presents the average duration of instalment indebtedness in each of the 5 principal types of establishments.

\section{Chart II}

AVERAGE DURATION OF INSTALMENT INDEBTEDNESS' IN FIVE TYPES OF RETAIL ESTABLISHMENTS $1928-1938$

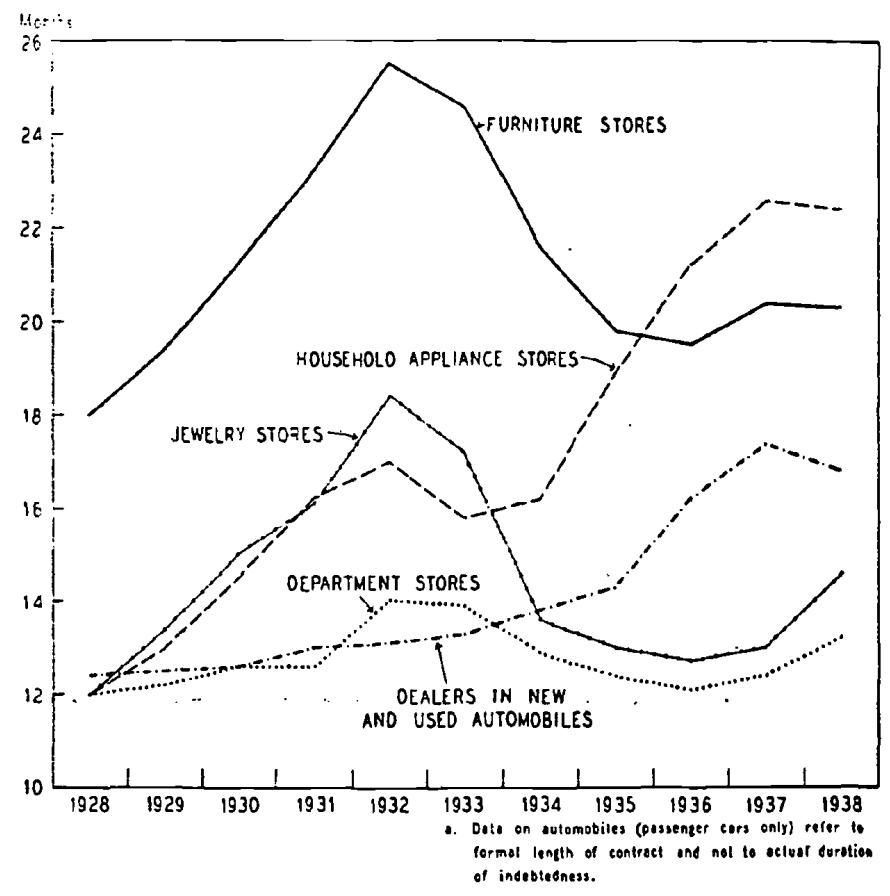

The duration of consumer indebtedness increased markedly during this ten-year period, especially in household appliance financing, for which the average paying-out time lengthened from 12 to 22 months. The entrance of government agencies into the instalment financing field may account to a large degree for this rapid liberalization of financing arrangements, since it encouraged public utilities to sell appliances on contracts extending for 36 months, and lending institutions to advance instalment loans for property improvement on terms of similar length.

The rapid rise in the duration of consumer instalment indebtedness during $1930-32$ is a direct result of delays in repayments occasioned by the recession. The continued effect of bad times upon repayments was still in evidence during 1933 , when the duration of indebtedness decreased but slightly. A return to more normal times in 1934 is indicated by the abrupt decline in the time required for instalment debt liquidation.

5 This represents an average of payment periods varying from 3 months for clothing (10-tweek payment plan) to 36 months or longer for refrigerators. 
Contract length for automobile instalment sales rose gradually from 12 to 17 months during the period covered by the data. In the case of automobile purchases, duration of indebtedness refers to the original contract length rather than to the actual time consumed in paring off the debt. These figures, therefore, do not show the effects of delinquent accounts, prepayments and note renewals as they do for the other retail groups.

Of two retail establishments extending the same amount of instalment credit, the one which allows the longer period for repayment will have on its books a greater proportion of the resultant instalment outstandings. The percent of total credit granted by each type of retail establishment, compared with its percent of total average outstandings, therefore illustrates differences in the payment period among the different types. In 1929, furniture stores accounted for 22 percent of total average outstandings, but for only 16 percent of the total credit granted, indicating that the average payment period in furniture retailing is longer than for retail establishments in general. The department store and automobile dealer series show greater proportions of total credit granted than of total outstandings, reflecting shorter average maturities in these two groups than prevail for all retail groups as a whole.

Approximately 6o percent of the number of all automobiles sold are financed on an instalment basis (Chart III). Household appliance and furniture stores also do a large instalment volume; the proportion ranged between 40 and 50 percent of their total sales during the ten-year period. Instalment sales amounted to 27 percent of total jewelry store sales in 1937 , and department store instalment sales amounted to 12 percent. Instalment selling in these two types of stores increased grad ually over the ten-year period studied.

In the automobile dealer group the percentage of cars sold on an instalment basis decreased. This decline may be attributed in part to the growing importance of the replacement market in the automobile trade. As a result, more buyers have used cars to trade in against both new-car and used-car purchases. ${ }^{\circ}$ To such buyers the value of "trade-ins" is tantamount to cash. When a great many purchasers have that start toward the purchase of a car, some of them who otherwise would have to buy on a time-payment basis will find that they can raise the rest of the money necessary to buy for cash. Perhaps another factor responsible for the decline in the percent of cars sold on an instalment basis is the fact that cash-lending agencies grant an increasing number of direct cash loans to be applied to automobile

- See "Composite Experience of Sales Finance Companies and Automobile Dealers," an annual publication of the National Association of Sales Finance Companies.

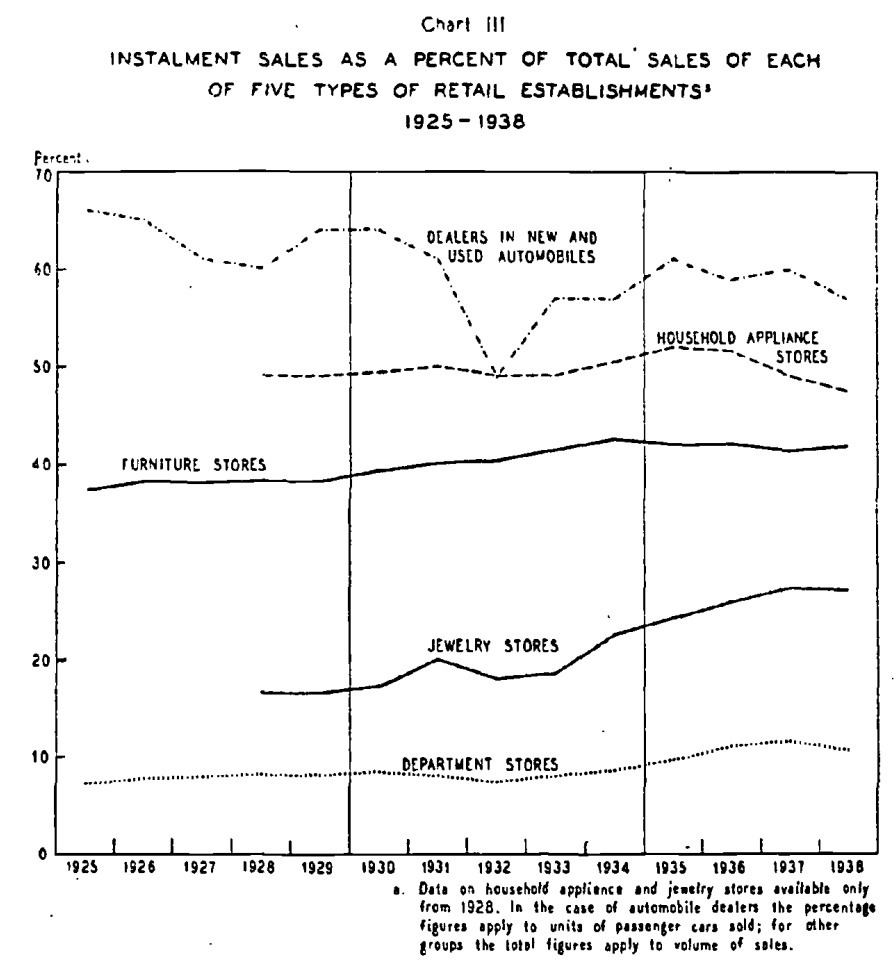

purchases. Such a purchase appears in the automobile dealer's records as a cash sale, although the loan itself is paid off in monthly instalments.

\section{INDIVIDUAL RETAIL SERIES}

\section{Automiobile Dealers}

The total amount of instalment credit granted for automobile purchases was over $\$ 2,000,000,000$ in each of three years-1929, 1936 and 1937. Average outstandings were highest in 1937 , when they totaled $\$ 1,523,-$ 900,000 , and repayments were highest in 1929 , amounting to $\$ 2,143,200,000$. Credit granted dropped 76 percent from 1929 to its lowest point in 1932, while outstandings declined 70 percent and repayments 71 percent from 1929 to 1933. Between 1933 and 1937, however, credit granted rose 271 percent, repayments 218 percent, and average outstandings 303 percent. Despite these marked increases, credit granted and repayments were one-tenth lower in 1937 than in 1929; average outstandings, however, were one-fifth higher. The greatest drop in outstandings in a single year took place in 1938 , when they decreased by $\$ 440,200,000$ or 28.4 percent.

Instalment sales for the automobile group, as reflected in credit extended, show wide seasonal movements, as indicated in Chart IV-A. May and June are the most important months for credit granting, and outstandings reach a seasonal peak during the fall months. Beginning with 1935 , when new car models were introduced at the end of each year, credit granted and out- 
standings show slight increases in December and January. For the most part the repayments curve is smooth, distinguished by little seasonal movement. ${ }^{7}$

\section{Department Stores}

Instalment credit grants by department stores reached a peak in 1937 of $\$ 441,200,000$, an 18 percent increase over the 1929 total. The low year in credit granted was 1932 , when the volume was $\$ 211,300$, 000-a 43 percent decrease from 1929. Average outstandings declined 37 percent between 1929 and 1933 , then rose to their highest point in $1937(\$ 238,800,000)$. Repayments, like credit granted, rose 18 percent between 1929 and the peak year 1937 , when they totaled $\$ 429,900$,000. The greatest changes in outstandings took place in 1932 and in 1936; in the former year outstandings decreased \$49,000,000 and in the latter they increased by the same amount. In general, the year-to-year movements of the

T This is because repayments during any one month result from operations during several preceding months, usually 12 to 18 . several credit items in the department store series were much less marked than in the autonobile series.

Monthly estimates for department stores show significant seasonal variations, which appear in Chart IVB. As in the automobile series, outstandings vary less than credit granted. The primary seasonal peak in both credit granted and outstandings occurs in . December, with a secondary peak in October for credit granted and in May or June for outstandings. The trough for both is usually in July or August.

Department store outstandings and volume of credit granted are greatest in the same month, whereas the automobile outstandings peak lagged two or three months behind the seasonal peak of credit granted. In December, department store credit granted considerably exceeds the volume of repayments, so that outstanding debt increases sharply; but in January credit grants drop very sharply below repayments, so that outstanding debt decreases. Automobile instalment sales, on the other hand, are heaviest in three or four

Chart IV

MONTHLY TOTALS OF INSTALMENT CREDIT GRANTED, REPAYMENTS AND OUTSTANDINGS FOR FIVE TYPES OF RETAIL ESTABLISHMENTS AND FOR THE FIVE TYPES COMBINED
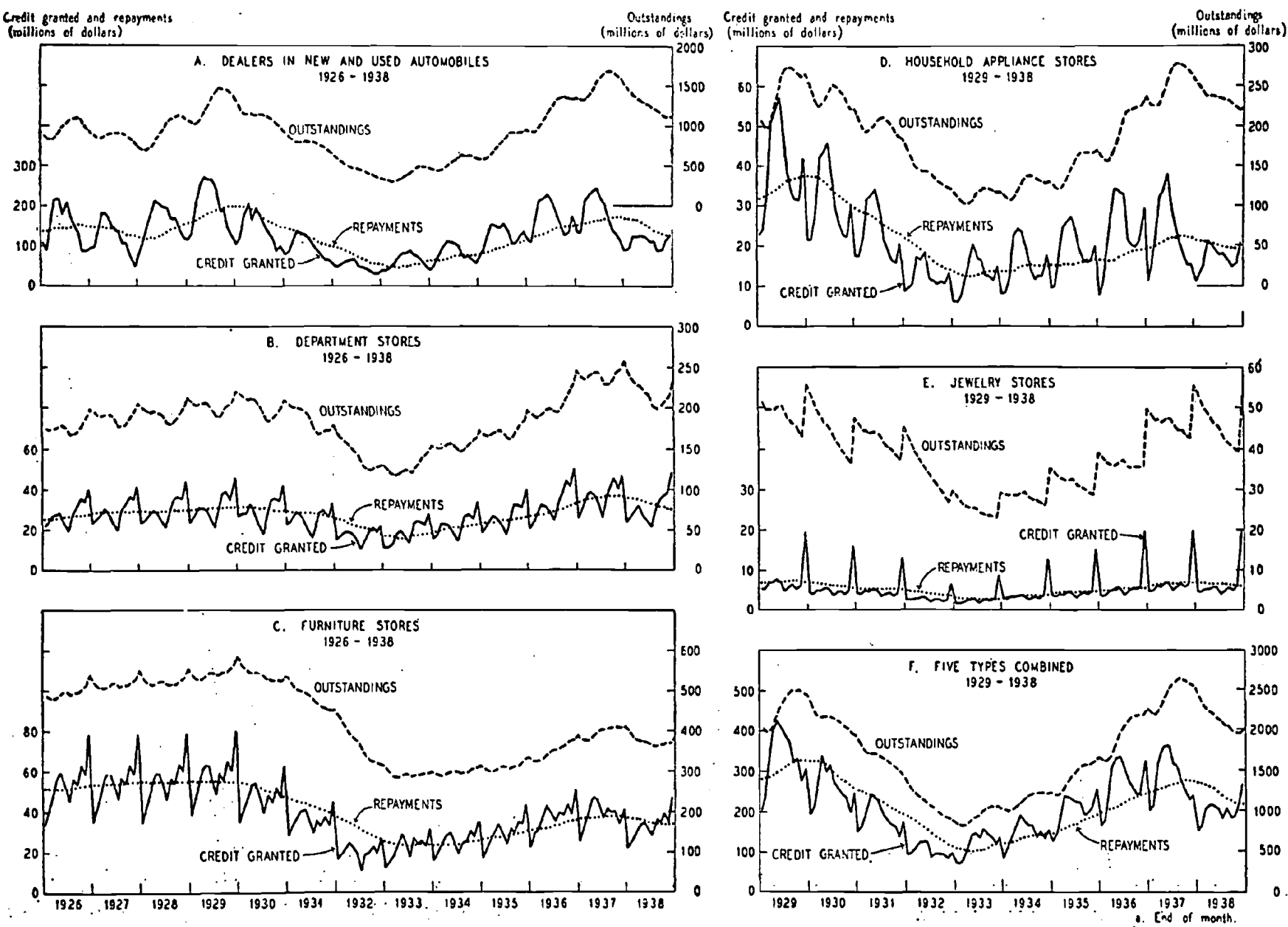
consecutive months (March to June), but they rise and fall at a moderate rate; so that for several months after the sales peak occurs the volume of credit granted continues to exceed repayments, and outstandings continue to rise.

\section{Fumiture Stores}

Furniture store instalment credit sales were greatest in $19: 9$, when almost $\$ 691,000,000$ worth of instalment credit was extended to consumers. During the same year arerage outstandings, totaling $\$ 541,900,000$, and repayments. amounting to $\$ 659,000,000$, were likewise at their highest figures. As in the automobile and department store series, the lowest point for credit granted was reached in 1932, when it was 66 percent below 1929, for arerage outstandings and repayments in 1933, when these items were 46 and 57 percent respectively below r929. Unlike the two series already discussed, however, the volume of furniture store sales never again approached its 1929 peak, and since the average duration of indebtedness was about the same in 1937 as in 1929, the volume of outstandings as well as of credit granted and repayments remained approximately 30 percent below the 1929 levels. The sharpest change in outstandings during any one year was the decrease of $\$ 140,600,000$ in 1932.

Monthly figures for furniture stores reveal seasonal movements very much like those which characterize the department store series (Chart IV-C). December is the peak month for credit granted and outstandings. Smaller seasonal peaks are registered for both items in October and in the spring months. The low month for the amount of credit granted is January; for outstandings it is February or March.

\section{Household Appliance Stores}

Credit granted and repayments were high in 1929 , with volumes of $\$ 466,800,000$ and $\$ 417,400$,000 respectively, but average outstandings were highest in 1937 , totaling $\$ 255,900,000$. Although credit granted and repayments fell approximately 40 percent from 1929 to 1937 , average outstandings rose 6 percent, as a result of a trend toward increasing the length of instalment contracts on household appliances. Credit granted fell 68 percent from 1929 to 1932 , reaching a low point of $\$ 149,200$,000 in the latter year. Repayments and outstandings decreased through 1933 , when the volume of repayments was $\$ 156,400,000$ and of outstandings $\$ 113,900,000$. These figures represent decreases from 1929 of 63 percent in reparments and 53 percent in average outstandings. The greatest changes in outstandings occurred in 1932, when they decreased by about $\$ 63,000,000$, and in 1936 , when they rose by $\$ 67,000,000$.
In spite of the fact that the number of appliances sold on an instalment basis increased greatly berween 19:9 and 1937, credit extensions by household appliance stores amounted to less in 1937 than in 1929. Most of this decrease may be traced to two factors. First, appliances became much less expensive. The tremendous decline in household appliance retail prices over the last ten years is well illustrated by data from a trade journal, which show that in 1938 the average retail price of electric refrigerators was $4 \mathrm{I}$ percent lower than in 1929, of washing machines 36 percent lower, and of electric ranges 19 percent. Radio prices declined 60 percent from 1929 through 1937. Vacuum cleaners were the one exception to this trend, increasing in price by 19 percent from 1929 to $19388^{\circ}$ Second, household appliances were being distributed through department stores, drugstores, furniture stores, hardware stores, mail order houses, and many other retail outlets besides appliance stores.

The primary seasonal peak in credit granted usually occurred in May or June, after a heavy concentration of sales for several months (see Chart IV-D). A secondary peak was also registered during December. The peak in outstandings lagged by one to three months behind that for credit granted, developing usually in July or August. January seems to have been the trough month for credit granted, and February or March for outstanding debt.

\section{Jerwelry Stores}

Of the five types of retail establishments covered in this study, the jewelry store group transacted the smallest volume of instalment business. Credit extended to consumers by jewelry stores was greatest in 1929 , totaling $\$ 88,800,000$, and almost as large in 1937 , when it totaled $\$ 84,600,000$. Average outstandings in each of these years came to approxinately $\$ 47,000$,ono. Credit granted, repayments, and average outstandings were lowest in 1933, when these items had decreased 64 percent, $6 \mathrm{I}$ percent, and 48 percent respectively from their 1929 levels. The greatest net change in end-of-year outstandings during one year was a $\$ 15,600,000$ decrease in 1932.

The monthly estimates for jewelry stores show striking seasonal changes (Chart IV-E). Extensions of instalment credit reach a tremendous seasonal peak in December; at least one-third of the annual instalment transactions of jewelry stores are made in that month, causing a sharp peak in outstandings as well.

s Electrical Merchandising, Statistical and Marketing Issue, January 1939. 
"All Other Stores"

The "all other stores" classification included many retail apparel and accessory outlets whose sales did not vary as much as those of most concerns selling on an instalment basis." The volume of credit granted was at its peak in 19:9. when it amounted to $\$ 296,600,000$. Repayments were highest in 1930 , totaling $\$ 276,700$,ooo, and average outstandings in 1938 , when they reached $\$ 195,000,000$.

As with the other groups in our series, credit granted was lowest in 1932 when the volume stood at $\$ 153,-$ 500,000 ; but $19 j 3$ marks the low point both for repayments $(\$ 152 ; 800,000)$ and for outstandings $(\$ 1$ i 6,500 ,ooo). These three figures represent decreases of 48 per- cent, 44 percent, and 33 percent respectively from the 1929 figures.

No figures were available for monthly estimates for stores in this classification.

Monthly Totals for the Fire Principal Retail Credit Establishments Combined

For the five major retail establishments combined, the heaviest concentration of credit granted occurred during the spring months (Chart IV-F), with another rise during December. Because automobile debt constitutes approximately one-half of total retail debt, the seasonal pattern in total credit granted is quite similar to that of the automobile series. Outstandings reached modified seasonal peaks during the summer months and in December.

\section{Estimates of Cash Loan Instalment Credit}

During the ten-year period covered by our estimates, total cash loan average outstandings ${ }^{10}$ were at their highest point in 1938 , when they averaged $\$ 1,124$,900,000 , or more than 100 percent above their 1929 level; they were lowest during the two years 1933 and 1934, when they approximated $\$ 460,000,000$. This is in contrast to retail instalment debt, which rose in 1934 and declined in 1938 .

The volume of credit extended to consumers by the four principal cash-lending agencies ${ }^{11}$ was likewise at a peak during 1938 , totaling $\$ 1,575,600,000$. Repayments reached a high in the same year with a volume of $\$ 1,516,800,000 .{ }^{12}$ The low year for both credit granted and repayments was 1933 , when these items totaled $\$ 584,300,000$ and $\$ 633,100$,000 respectively; they then began to rise, increasing approximately $170^{\circ}$

- These establishments are as follows: country general stores, drygoods and general merchandise stores, gasoline filling stations, garages, automobile tire and accessory stores and other automotive stores, the entire apparel group, hardware stores, bookstores, sporting goods stores, florists, secondhand stores, drugstores, bicycle shops, fuel and ice dealers, gift, novelty and souvenir shops, and luggage stores.

10 These figures include commercial banks, credit unions, industrial banking companies, personal finance companies, and unregulated lenders; as well as insured FHA (Title I) loans of $\$ 2,000$ or less.

11 Commercial banks, credit unions, industrial banking companies, and personal finance companies. Unregulated lenders and FHA loans are excluded. The estimates of credit granted by cash-lending agencies include renewals of loans (old balances renewed). If an outstanding loan for $\$ 50$ is renewed, $\$ 50$ is added to payments due in that month and $\$ 50$ to loans made. The result is an increase in both loans made and payments due; outstandings, however, remain the same.

12. Estimates of repayments to cash-lending agencies include accounting collections on old balances renewed. percent and 140 percent respectively by $193^{8}$ to volumes 60 percent and 76 percent above 1929.

End-of-month outstandings for the four principal types of lending institutions and for FHA loans are shown combined and singly in Chart V. Total outstandings increased in 1929 and 1930, decreased gradually until the end of February 1934, and again moved upward; from March 1934 to the close of 1938 they increased 167 percent, and were still rising at the close of December 1938, the last month to which our estimates apply.

A marked cyclical movement is exhibited by the personal finance company and the industrial banking company curves shown in Chart V. Personal finance company outstandings rose steadily from I 929 until January 193 I, and declined gradually to a low point at the end of October i933. From this date to the close of 1937 , the loan balances of these companies increased 54 percent. Industrial banking company outstandings fluctuated more, dropping 48 percent from the end of the expansion period 1929-30 to February 1934, and rising almost roo percent by the end of 1938 .

The commercial bank and credit union curves in Chart V move in the same way cyclically as the personal finance company and industrial banking company curves during 1932-33, but show a tremendous secular growth in the period 1934-38. Consumer loan balances of these agencies showed decreases of $3^{6}$ percent and 2 I percent respectively during 193 I-33. During $1934-38$, however, indebtedness to credit unions multiplied more than four times, and to commercial banks more than eight times.

Insured FHA (Title I) loans were first made in r 934. 
Chart V

MONTHLY TOTALS OF INSTALMENT LOAN OUTSTANDINGS" FOR FOUR TYPES OF CASH LENDING INSTITUTIONS, FOR FHA LOANS, AND FOR THE FIVE SERIES COMBINED $1929-1938$

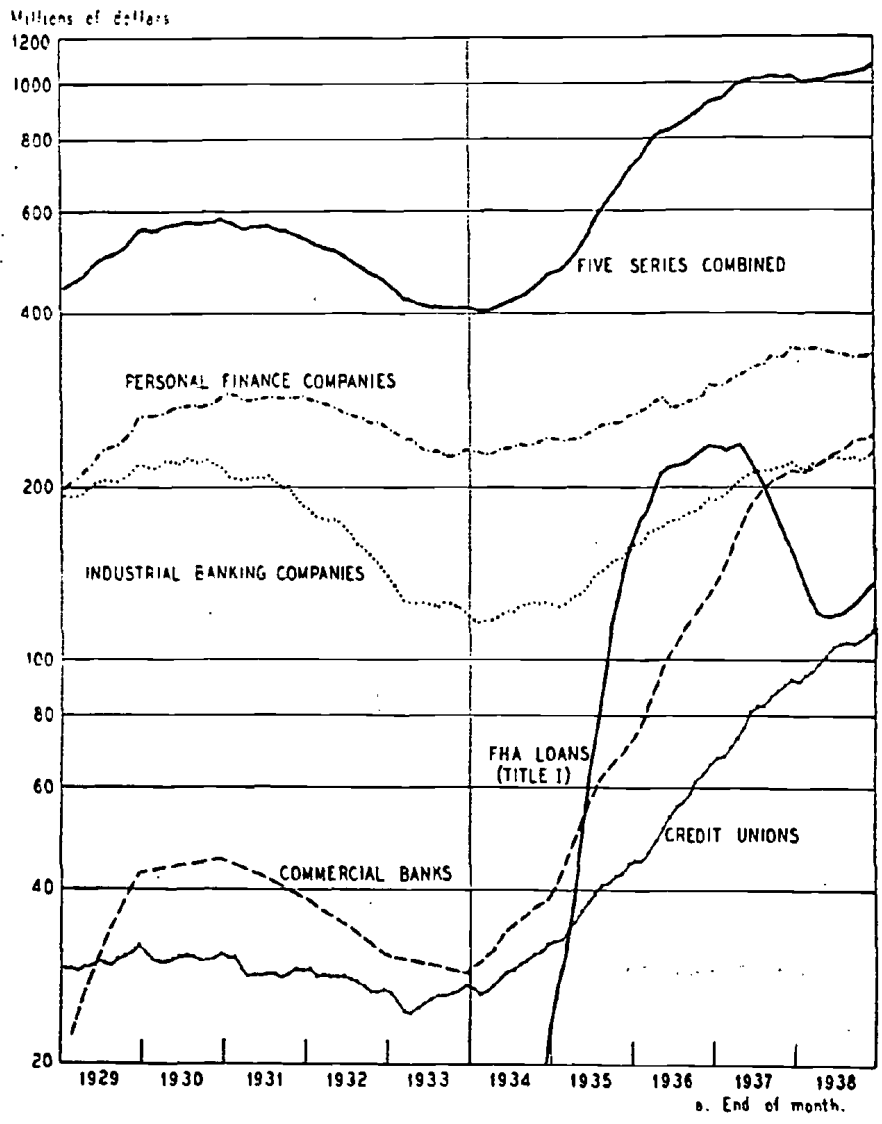

Average outstandings were highest during 1936, when they amounted to 24 percent of total outstandings of all cash-lending institutions combined. These loans were discontinued, however, during most of 1937 , with the result that in 1938 outstandings were only II percent of the total.

During 1929-38 personal finance companies held a decreasing proportion of the total loan balances of all lending institutions, and in this same period average outstandings for industrial banking companies also declined in relation to other lending agencies; the share of the former dropped from 42 to 31 percent in the ten-year period, and that of the latter was almost cut in half (40 percent to 20 percent). These decreases reflect the rapid growth of commercial banks and credit unions in the cash loan field; in 1929 only I I percent of total cash loan indebtedness arose from these two types of institution, but in 1938 they were responsible for almost 30 percent. It does not follow, however, that the loan balances of personal finance companies and industrial banking companies fell off during this period; the cash loan group as a whole more than doubled its rolume of business during the ten-year period, and within the group the outstandings of personal finance companies rose 50 percent and that of industrial banking companies to percent. The share of total average outstandings held by unregulated lenders changed little during this period, remaining close to 8.5 percent.

\section{INDIVIDUAL CASH LOAN SERIES}

\section{Commercial Banks}

Credit extended to consumers through personal loan departments of commercial banks was greatest in 1938 , when it totaled $\$ 374,900,000$. Repayments, amounting to $\$ 341,900,000$, and average outstandings, totaling $\$ 228,500,000$, were also highest in that year. Volume of repayments touched the low point in 1929 and volume of loans made in 1933 , but average outstandings were low $(\$ 30,000,000)$ in both these years. The year 1937 witnessed the greatest change in outstandings, a net increase of $\$ 84,800,000$.

In connection with this great rise in loan volume between 1933 and 1938, it should be remembered that the number of personal loan departments in commercial banks grew rapidly in that period. Of 1,095 banks reporting personal loan departments to the National Bureau of Economic Research in 1938,80 percent had established these departments after $1932 .{ }^{13}$

Monthly estimates for commercial banks (Chart VIA) do not show the distinct seasonal patterns which appear in the retail series. Outstandings changed very little during the period, but the volume of loans made shows a December seasonal peak, and a secondary peak in June. The repayments curve moves in very much the same direction as the credit granted curve. ${ }^{14}$

\section{Credit Unions}

Credit unions are quantitatively the least important of the four principal types of lending institutions. Total average outstandings of credit unions were highest in $193^{8}$, when they amounted to $\$ 102,600,000$. Loans made and repayments were also highest in 1938 , totaling $\$ 179,400,000$ and $\$ 159,200,000$ respectively in that year.

These three credit items were at a low point in 1933, when loans made came to $\$ 32,500,000$, repayments to $\$ 32,000,000$, and average outstandings to $\$ 25,900,000$. The greatest change in loan balances occurred in 1937 , when outstandings rose by $\$ 26,800,000$. At the close of

${ }^{13}$ National Bureau of Economic Research (Financial Rescarch Program), Conmercial Banks and Consumer Instalment Credit, by John M. Chapman and Associates (1940), Table 1, p. 28. ${ }_{14}$ This is because accounting collections on old balances renewed were included in the total repayments figures. 
$193^{8}$ average outstandings were 242 percent higher than they had been in 1929 .

Monthly figures for credit union outstandings reveal no discernible seasonal pattern (Chart VI-B). Monthl! data covering loans made and repayments for these institutions are not available.

Chart VI

MONTHLY TOTALS OF INSTALMENT LOANS MAOE, REPAYMENTS AND OUTSTANDINGS FOR FOUR TYPES OF CASH LENDINC INSTITUTIONS, FOR FHA LOANS, AND FOR THE FIVE SERIES COMBINED
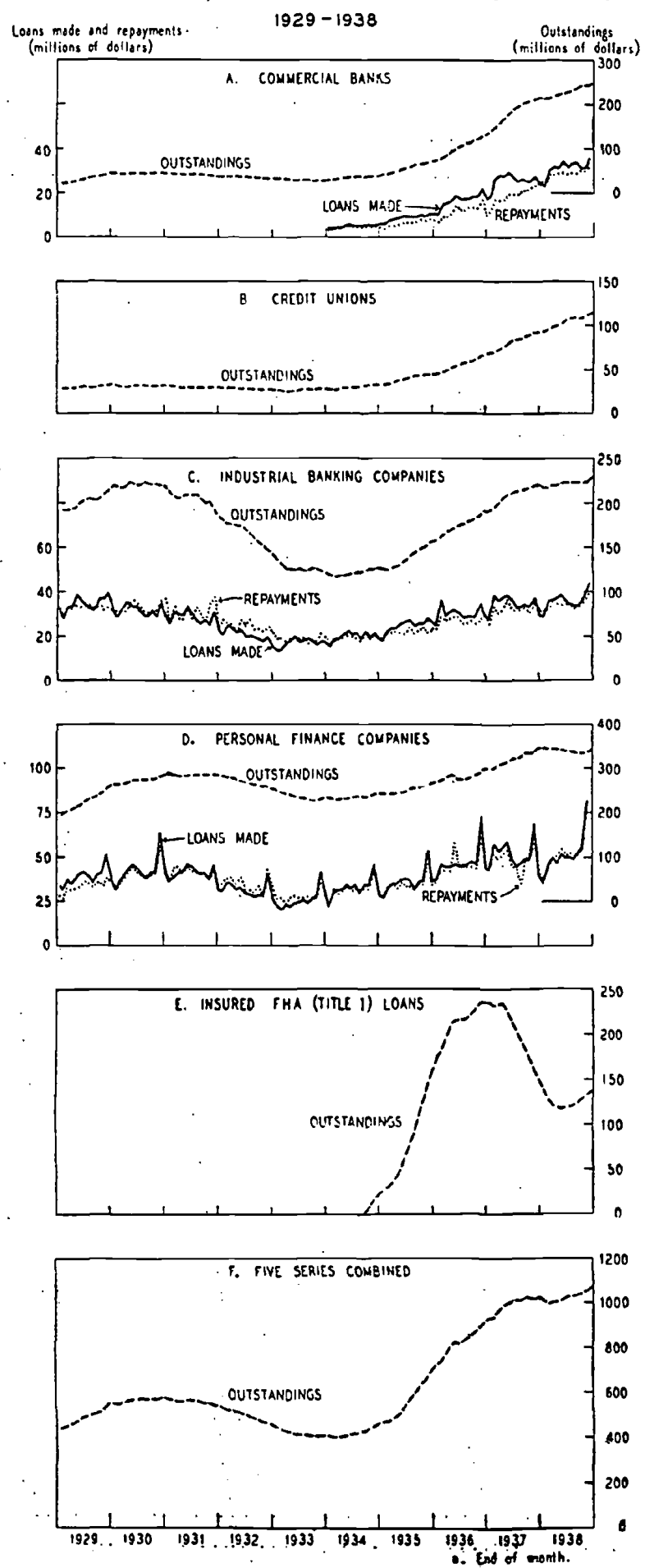

\section{Industrial Banking Companies}

Unlike the commercial bank and credit union figures, the industrial banking company series show no eridences of growth trend. Loans made by industrial banking companies during the ten-year period reached a peak of $\$ 416,900,000$ in 1938 , and repayments, amounting to $\$ 407,500,000$, were likewise at their high point in that year. Both these items showed relatively little change from the pre-depression high points of 1929 . Average outstandings were at almost the same high points in $193^{\circ}$ and 1938 ( $\$ 220,100,000$ and $\$ 222,800,000$ respectively).

Loans made and repayments declined gradually from 1929 through 1933, when they reached $\$ 201,600,000$ and $\$ 224,000,000$ respectively. Average outstandings fell to $\$ 120,500,000$ by the end of 1934 , and the greatest change in this item took place during 1932, when there was a $\$_{4} 1,300,000$ net decrease.

Credit granted and repayments, by months, for industrial banking companies do not show any pronounced seasonal movement, although they tend to rise in December, and some slight concentration of loans made appears during the spring months (Chart VI-C). For both items the seasonal low occurs in January and February. The outstandings curve shows no distinct seasonal pattern.

\section{Personal Finance Companies}

The volume of instalment credit extended to consumers by personal finance companies reached its high point $(\$ 615,300,000)$ in 1937 , and was almost as high in $193^{8}(\$ 604,400,000)$. Repayments and average outstandings were highest in 1938 ( $\$ 608,200,000$ and $\$ 347$,600,000 respectively). Loans made and repayments were lowest in 1933, and average outstandings remained at a low point (approximately $\$ 236,000, \infty 00$ ) during the two years 1933 and 1934. A rise of $\$ 70,000$,ooo during 1929 constituted the greatest change in outstandings over the ten-year period.

In general, the series for personal finance companies are more stable than those for other institutions in the cash loan group; compared to other lending institutions their loan balances declined little during 1932-34 and increased slowly during the $1935-3^{8}$ period of expansion.

Monthly figures on personal finance companies show that for loans made and repayments there are pronounced seasonal peaks in December and troughs in January or February (Chart VI-D). Month-end outstandings likewise come to a slight peak in December.

It is interesting to note that in June $193^{6}$ personal finance outstandings showed a sudden decrease of 4 percent, due to repayments made after the distribution of the Veterans' Bonus: 


\section{Umegulated Lenders}

Figures on unregulated lenders have been included in order to complete the instalment credit totals for all types of cash-lending agencies, but these estimates are for annual outstandings and net credit change only. Average outstandings for such institutions were highest during 1938 ( $\$ 96,100,000)$, lowest in $1933(\$ 38,600$,$000)$. The greatest net credit change was an increase of $\$ 19,500,000$ in 1936 .

\section{Insured FHA (Title I) Loans}

Average outstandings on FHA (Title I) loans of $\$ 2,000$ or less reached a high point of $\$ 211,100,000$ during 1936. The greatest change in actual outstandings took place in 1935 , when this iten increased by $\$ 140,200,000$. Actual month-end outstandings reached a peak point of $\$ 237,100,000$ in November 1936 (Chart VI-E). Monthly data covering loans made and repayments for FHA loans are not available.

\section{Estimates of Retail and Cash Loan Instalment Credit Combined}

Total average instalment indebtedness was $\$ 3,719,800$,ooo in 1937 , the high point of the ten years covered by this study. ${ }^{15}$ The low point was 1933, when indebtedness totaled $\$ 1,5_{11}, 200,000$. Both in 1937 and 1938 the amount of instalment indebtedness was larger than in 1929 , when it was approximately $\$ 3,000,000$,000.

Indebtedness arising from retail instalment transactions accounted for approximately 75 percent of all instalment debt during the ${ }^{1929-38}$ period as a whole, but its relative importance fell from 82 percent of the total in 1929 to 67.5 percent in 1938. Cash loan debt makes up a larger proportion of total instalment debt during recession years than during times of business revival, retail debt decreasing sharply during periods of recession. In the revival years after 1933, however, cash loan debt accounted for a substantially larger proportion of total debt than it did in 1929; for example, in 1937 it made up 29 percent of total instalment debt, compared to 17.7 percent in 1929 .

The trends shown by cash loan instalment debt differ from those shown by retail instalment debt. In 1938 the average amount of cash loan debt was more than twice as great as it had been in 1929 , while retail debt was 5 percent lower. Cash loan debt as a whole showed a slight increase in 1930, but retail instalment debt dropped sharply in the latter year. Retail debt rose during 1934 and declined during 1938 , while cash loan outstandings were lowest in 1933-34 and at their highest point in 1938 .

Total indebtedness followed a direction generally similar to that of retail indebtedness. This is to be expected, since retail instalment debt made up approximately three-fourths of total consumer instalment debt during the period covered. According to Chart VII, which shows the indices of average outstandings. for

15 Totals include the six types of retail establishments, and all types of cash loans including the series of insured FHA (Title I) Joans. the retail, cash loan, and composite groups, ${ }^{10}$ from 1929 to 1933 the composite index declined about 50 percent and the retail index about 60 percent, while the cash

Chart VII

INDICES OF AVERAGE ANNUAL INSTALMENT OUTSTANDINGS FOR ALL TYPES OF RETAIL ESTABLISHMENTS AND CASH LENDING INSTITUTIONS

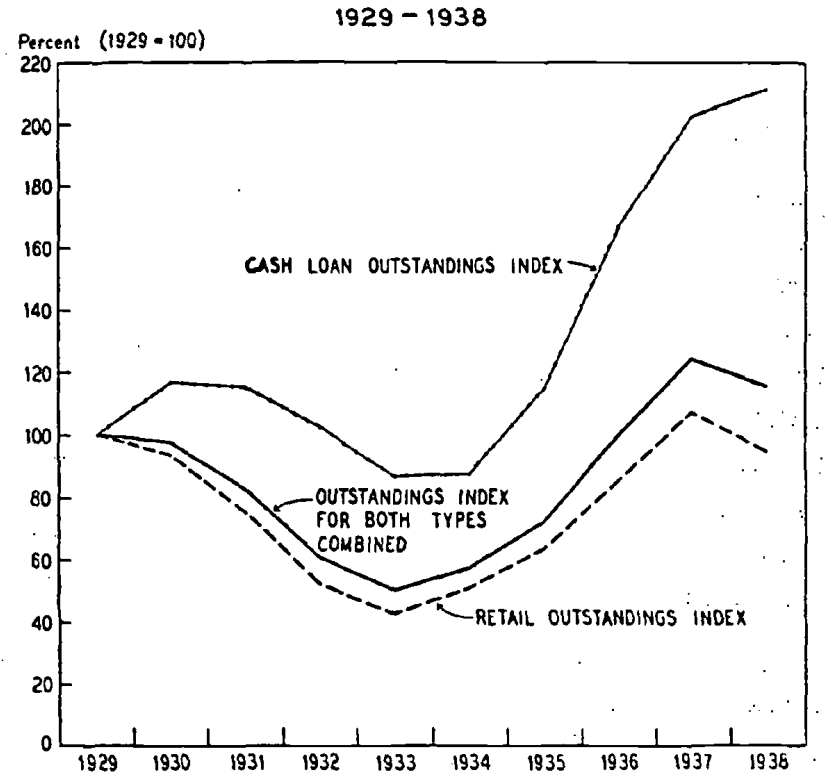

loan index decreased 15 percent. After 1933 total indebtedness rose to a new high in 1937 , when it was almost 24 percent above its 1929 amount. Retail indebtedness in 1937 was 7 percent over its 1929 volume, and cash loan indebtedness was 103 percent higher; but in 1938 total indebtedness and retail indebtedness fell off, while cash loan debt continued to rise. This steady increase in cash loan debt was occasioned by a striking growth in the loan business of commercial banks and credit unions.

${ }^{16}$ Including all types of agencies, both retail and cash loan, and insured FHA (Title I) loans. 
Instalment debt arising from automobile purchases accounted for 25 to 42 . percent of total instalment debt during 1929-38. Furniture stores were responsible, on the average, for about 16 percent of total debt during the period, and personal finance companies for il percent. The proportion of total outstandings held by commercial banks and credit unions combined was 6.9 percent in 1937 , whereas it had been only 2 percent in 1929.

The total volume of credit granted by the major credit agencies in both groups ${ }^{1:}$ reached its peak in 1929 at $\$ 5,282,000$,000, and in 1937 it was almost as high $(\$ 5,145,000,000)$. Repayments were high in $1929(\$ 4,-$ $802,000,000)$ and rose further in 1930 , to their peak of $\$ 4,821,000,000$. Outstandings showed a marked decrease in 1932, when repayments excoeded credit granted by $\$ 711,000,000$; but in 1936 they increased by $\$ 773,000,000$, the greatest net change in outstandings during the period studied.

The monthly movement of outstandings for the principal agencies covered in our estimates ${ }^{18}$ appears in Chart VIII. Total outstandings reached a peak at the close of September 1937, having risen 15 percent above the previous peak point (October 1929) and 195 percent above March 1933, the low point of the ten-year period. Between October 1929 and March 1933 total outstandings fell 59 percent. The peak in total instalment debt which occurred at the end of September 1937 was 15 percent above the previous peak point in October 1929. Retail outstandings show some seasonal movement, rising in the spring months and again in December; but cash loan outstandings show practically no seasonal pattern. Outstandings for both types of credit combined show a slight seasonal movement which follows, as would be expected, the pattern of retail outstandings.

\section{INSTALMENT CREDIT IN RELATION TO INCOME PAYMENTS}

According to the evidence assembled in the consumer instalment financing studies of the National Bureau, the vast bulk of consumer instalment credit is extended to individuals whose annual incomes do not exceed \$5,000. A comparison of the present instalment credit series with estimates of total income payments received by these individual consumers from $1929-38$ shows that an average of approximately 9 percent was added to

17 Including the six types of retail establishments; excluding unregulated lenders and insured FHA (Title I) loans from the cash loan group.

18 Excluding "all other stores" from the retail group, and unregulated lenders from the cash loan group.

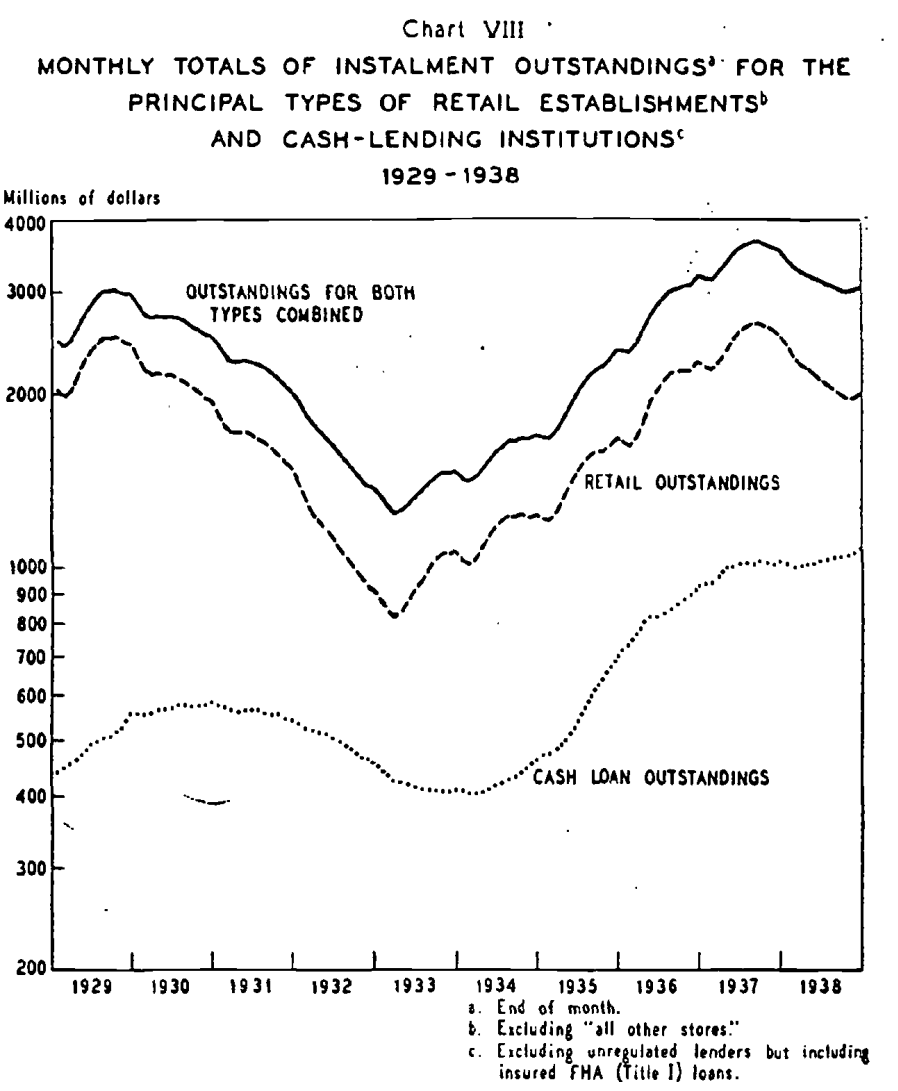

their total purchasing power by instalment credit, while repayments of such credit absorbed on the average a similar proportion of their total income. At the bottom of the 1929-37 business swing (1932), instalment credit granted amounted to only 6 percent of the aggregate income of the consumers using it, but at the top of the swing (1937) it amounted to 11 percent. Repayments, lagging cyclically behind credit granted, reached a low in 1933 of 6.4 percent of the aggregate incomes of consumers using instalment credit, and a peak of 11 percent in 1938 .

In years of business advance, instalment credit granted consistently exceeded repayments of instalment debt, giving rise to a net addition to the stream of consumer purchasing power. In each year of business contraction, a net drain on consumer purchasing power was created. The maximum net addition to purchasing power during this ten-year period occurred in 1936 , and the largest net drain in 1932. In both years, however, the amount involved was relatively small, roughly 2 percent of the total income of consumers receiving annual incomes of $\$ 5,000$ and less. The economic significance of consumer instalment credit, however, is not to be judged solely by its quantitative amount relative to total income payments. 